\title{
The nature of urinary casts
}

\author{
E. G. MCQUEEN ${ }^{1}$ \\ From the Department of Experimental Pathology, University of Birmingham
}

SYNOPSIS The composition of hyaline casts has been investigated. The major constituent appears to be the urinary mucoprotein described by Tamm and Horsfall. Small amounts only of serum proteins are present.

Neither the amounts excreted nor the concentration of Tamm-Horsfall protein appeared to determine the rate of cast formation. The only invariable association of hyaline cast formation was with the presence of significant amounts of serum proteins in the urine.

In vitro it was found that aqueous solutions of serum albumin were particularly effective in producing precipitation of Tamm-Horsfall protein. This interaction was inhibited in normal urine but occurred to a greater extent in nephrotic urine and is suggested as the possible mechanism of hyaline cast formation.

The significance of casts in indicating the presence of renal disease has been recognized for well over 100 years (see Fishberg, 1954). It has usually been accepted that they are composed of urinary proteins precipitated at sites along the tubule where conditions of concentration, $p \mathrm{H}$, etc., are appropriate, and at least tacitly assumed that the proteins are mainly of plasma origin. The presumptive site of the formation of casts within the distal tubules and in the collecting system has been demonstrated by microdissection (Oliver, 1945). Addis $(1929,1948)$ showed that the material of which hyaline casts is composed may be dissolved in a dilute solution of alkali and reprecipitated by acidification and an increase in salt concentration. He showed that the material contained a sugar and suggested that hyaline casts consisted of a combination of protein with a polysaccharide. (Addis suggested specifically chondroitinsulphuric acid.)

In the present series of investigations attention has particularly been directed towards the possible role played in the formation of casts by the mucoprotein described first by Tamm and Horsfall $(1950,1952)$. This is a normal constituent of urine and has certain characteristics, such as a tendency to precipitation with increased crystalloid concentration of urine and greater solubility in alkaline solution, which it shares with casts. In fact it has already been sug-

'On leave from the Department of Medicine, University of Otago, New Zealand.

Received for publication 13 December 1961 . gested as the probable composition of cylindroids (Vaerman and Heremans, 1959).

\section{METHODS}

Tamm-Horsfall protein was obtained from normal and abnormal urine by the following method. To normal urine was added an equal quantity of $1 \cdot 16 \mathrm{Molar} \mathrm{NaCl}$. The deposit obtained on centrifugation, after having been washed three times with $0.58 \mathrm{M} \mathrm{NaCl}$, was dissolved in a large excess of alkalinized distilled water $(\mathrm{NaOH}$ to $p \mathrm{H} 9)$. This was again centrifuged to remove all debris still present. The supernatant was brought to $0.58 \mathrm{M}$ by addition of $\mathrm{NaCl}$, whereupon the TammHorsfall protein precipitated and was collected by further centrifugation. After washing with $0.58 \mathrm{M} \mathrm{NaCl}$ this material was ready for injection into rabbits for preparation of the anti-Tamm-Horsfall antiserum.

For the performance of electrophoresis on agar or paper, the material was dissolved in alkalinized distilled water and dialysed against distilled water for a prolonged period to remove mineral ions. As pointed out by Grant (1959), Tamm-Horsfall preparations when freshly made will frequently not diffuse through agar (or filter paper), whereas after having been allowed to stand in the cold for a prolonged period diffusion would occur. Grant (1959) has shown that urinary mucoprotein in normal urine colloid concentrates, immunologically identical with salt-precipitated Tamm-Horsfall protein, is not electrophoretically homogeneous, and similar observations have been presented by Vaerman and Heremans (1959). These data suggest that polymer series of uromucoids may exist, immunologically identical with TammHorsfall protein but having graded physical character- 


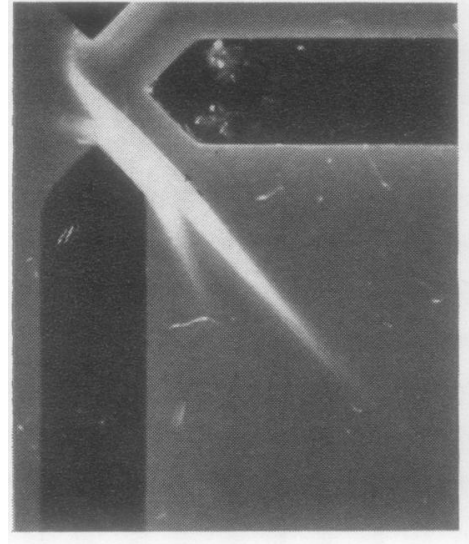

a

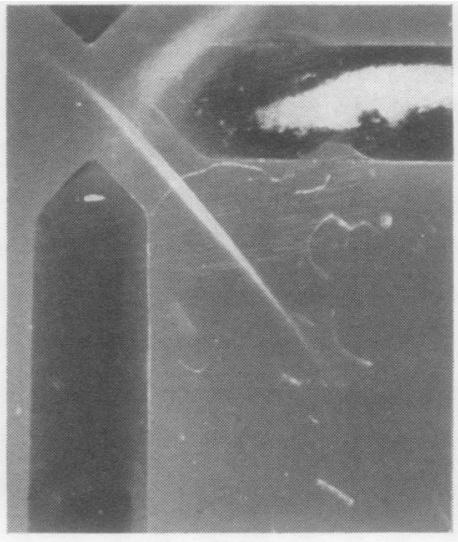

b

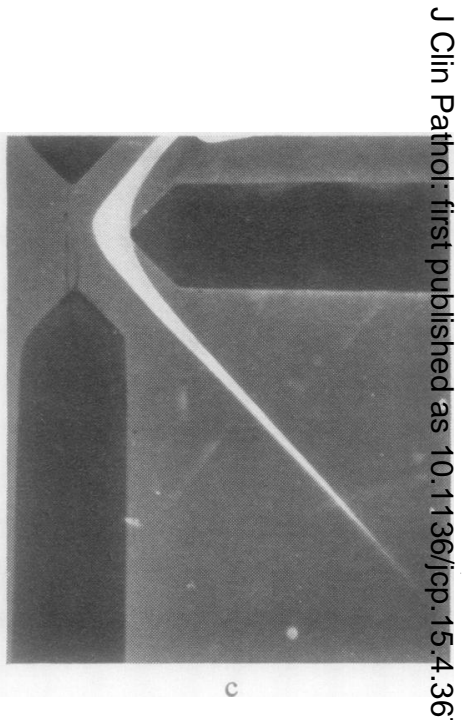

FIG. 1. (a) Vertical trough: alkali-treated Tamm-Horsfall protein. Horizontal trough: rabbit anti-Tamm-Horsfêl antiserum. (b) Vertical trough: $\alpha_{2}$ glycoprotein (M.W.900,000). Horizontal trough: corresponding antiserum. (c) Vertięal trough: $7 S$ y globulin $(M . W .177,000)$. Horizontal trough: corresponding antiserum.

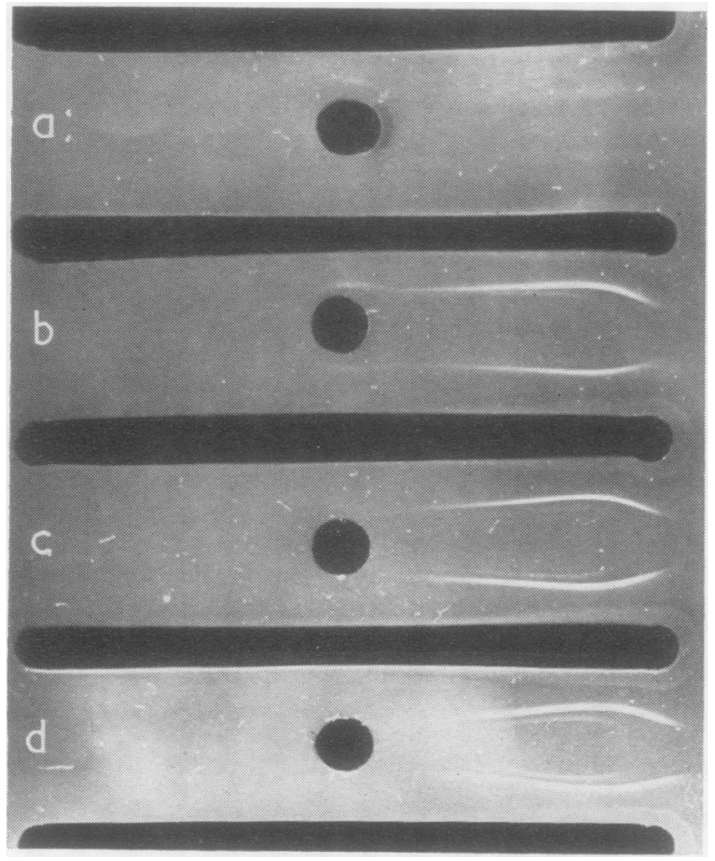

FIG. 2. Effect of alkali treatment on Tamm-Horsfall protein.

Troughs: Antiserum to Tamm-Horsfall protein prepared in the rabbit (diluted 1:1 with $p \mathrm{H} 8.6$ barbitone buffer). Holes (a) to (d) contain Tamm-Horsfall protein $(6.0 \mathrm{mg} . /$ $\mathrm{ml}$.) diluted (a) with barbitone buffer $1: 1$, (b) with $M / 20$

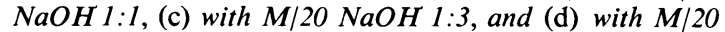
$\mathrm{NaOH} \mathrm{1:7.}$

Note that in (a) only a small amount of the material has diffused through the agar. istics. Spontaneous alteration in the polymeric state $\vec{\oplus}$ preparations of Tamm-Horsfall protein on storage presumably accounts for the differences observed in thegr diffusibility.

Modification of the physical characteristics of Tam Horsfall protein by freezing and by treatment with alk Hi $_{1}$ has been noted by Boyce and Swanson (1955) and after treatment with urea (Curtain, 1953). Alkali treatment has been shown (Boyce and Swanson, 1955) to conve्ञt Tamm-Horsfall protein to a more soluble but st homogeneous form. Because Tamm-Horsfall protein $\frac{\mathrm{as}}{\mathrm{g}}$ prepared above diffuses too poorly through agar for the satisfactory performance of filter-paper or agar-plate electrophoresis it was found best to add $\mathrm{M} / 20 \mathrm{NaOH} \%$ the material. This treatment does not impair its immunglogical specificity provided it is performed shortly before use. On gel-diffusion against anti-Tamm-Horsfall anaserum alkali-treated Tamm-Horsfall protein gives to precipitin lines. Using the double-diffusion technique of Allison and Humphrey (1960) in which the reactants a placed in troughs at right angles, the principal precipitation line occurs at an angle of $42^{\circ}$ with the antigen trough (Fig. 1, a). This would indicate for this componeres, according to the formula worked out by the aboke authors, a diffusion coefficient of $3.1 \times 10^{-7} \mathrm{~cm}^{2} \mathrm{sec}_{\mathbb{N}}^{\mathbb{N}}$ The precipitation line for $\alpha_{2}$ glycoprotein (MW. 900,000) against the corresponding antiserum occurred at $4 \overline{\mathbb{Q}}$ (Fig. 1, b), and that for 7S $\gamma$ globulin (M.W. 177,000) $44^{\circ}$ (Fig. 2, c), giving diffusion coefficients respectivefy of 2.7 and $3.5 \times 10^{-7} \mathrm{~cm}^{2}$ sec. $^{-1}$. These data suggest the the principal reacting component in alkali-treated prot parations of Tamm-Horsfall protein is of considerabळ smaller size than the smallest substituent defined bo physical methods (Maxfield, 1959, 1960, 1961) which has a molecular weight of $1.7 \times 10^{6}$. The second componeat diffuses more slowly but gives too diffuse a precipitatio zone to permit any quantitative estimate of the diffusibility. Immunoelectrophoresis in agar before and afto 
the addition of varying amounts of $\mathrm{M} / 20 \mathrm{NaOH}$ is illustrated in Figure 2.

Casts were prepared from the urine of nephrotic patients whose urine contained large numbers of these structures. The casts were mostly hyaline but some epithelial and granular casts were also present. After preliminary dilution of the urine with 3 volumes of distilled water with the intention of minimizing deposition of Tamm-Horsfall protein not in cast form the urinary deposit was separated by centrifuging at 1,000 r.p.m. for five minutes. The deposit was washed three times with physiological saline ( $p \mathrm{H} \mathrm{7.0)}$ and finally once with alkalinized distilled water $(p \mathrm{H} 9.0)$, shaking each time by hand. The deposit could then still be seen on microscopy to contain large numbers of casts together with epithelial cells and leucocytes. However, after taking up the deposit in about 40 volumes of alkalinized distilled water and agitating violently with a mechanical shaker for five minutes, the deposit on recentrifugation contained only occasional casts, although cells and cell debris were still evident.

The supernatant fluid from this operation was thought to contain the material of which the casts were composed. It was brought to $0.58 \mathrm{M}$ with $\mathrm{NaCl}$ upon which a substance resembling Tamm-Horsfall protein, i.e., a colourless semi-transparent gelatinous material ('cast-deposit'), came out of solution and was deposited by centrifugation. This material was used for preparation of an 'anti-cast antiserum' by injection into rabbits. For examination by filter-paper and immuno-electrophoresis the deposit was prepared as previously described for the Tamm-Horsfall protein.

The supernatant remaining after precipitation of the 'cast-deposit' with $0.58 \mathrm{M} \mathrm{NaCl}$, the 'cast-supernatant', was dialysed against distilled water and then concentrated 200 hundred times by negative pressure dialysis. It was then examined for the presence of serum proteins by gel-diffusion.

The techniques used for paper and immunoelectrophoresis were those described by Hardwicke (1954) and by Williams and Grabar (1955). The gel-diffusion technique was the Ouchterlony-Elek (Elek, 1948; Ouchterlony, 1958) and its adaptation (Gell, 1957) for quantitative estimation of small concentrations of protein was used to measure the amounts of serum proteins present in the 'cast-supernatant'. Methods used for preparing antisera were as described by Soothill (1962).

Quantitation of Tamm-Horsfall excretion was carried out as follows. To $20 \mathrm{ml}$. aliquots of urine was added $0.68 \mathrm{~g}$. of $\mathrm{NaCl}$. After standing for 30 minutes the urine was centrifuged, the supernatant decanted, and the deposit taken up with $20 \mathrm{ml}$. of alkalinized distilled water (brought to $p \mathrm{H} 9.0$ with $\mathrm{NaOH}$ ). After thorough shaking, cell debris, etc., was removed by further centrifugation. Tamm-Horsfall protein was then reprecipitated by adding $0.68 \mathrm{~g}$. $\mathrm{NaCl}$ to the supernatant and separated by centrifuging again. The deposit was washed once with $0.58 \mathrm{M} \mathrm{NaCl}$ and the amount of Tamm-Horsfall material, now presumed to be the only protein left, estimated by the Folin-Ciocalteau method, using a standard albumin solution as reference. A check on the adequacy of washing using a precipitate formed by the interaction of
Tamm-Horsfall protein and ${ }^{131} \mathrm{I}$-labelled albumin indicated that only a very small amount of albumin remained (vide infra). Varying amounts of Tamm-Horsfall protein within the range encountered gave a straight line versus optical density at $700 \mathrm{~m} \mu$. By reference to the dry weight of an aliquot of a solution of Tamm-Horsfall protein the actual amounts of Tamm-Horsfall protein being excreted were calculated.

For the estimation of the Tamm-Horsfall protein excretion rate it was necessary to be sure that its precipitation after the addition of $\mathrm{NaCl}$ to $0.58 \mathrm{M}$ concentration was complete. The supernatant fluid remaining after precipitation of Tamm-Horsfall protein from a specimen of normal urine with $\mathrm{NaCl}$ was dialysed against distilled water for five days to remove the $\mathrm{NaCl}$ and then concentrated 60 times by negative pressure dialysis. The amount of Tamm-Horsfall protein in the concentrated supernatant was then estimated by the gel-diffusion precipitin method (Gell, 1957) using multiple dilutions of anti-Tamm-Horsfall antiserum and of a standard solution of Tamm-Horsfall protein of known strength for comparison. The result indicated that about $5 \%$ of the total Tamm-Horsfall protein in normal urine was not precipitated by $0.58 \mathrm{M} \mathrm{NaCl}$.

\section{RESULTS}

The material obtained after solution of the casts in alkalinized distilled water and subsequent deposition by the addition of saline, etc. ('cast-deposit'), was subjected to paper and immuno-electrophoresis after preparation as described.

On paper electrophoresis at $p \mathrm{H} 8.6$ the alkalinized cast material could be seen to have the same mobility as Tamm-Horsfall protein from normal urine, a little less than that of serum albumin, corresponding to that found by Boyce and Swanson (1955) for alkali-treated Tamm-Horsfall protein. It gave position staining reactions for protein (bromphenol blue) and carbohydrate (periodic-acid-Schiff).

On immuno-electrophoresis precipitin bands of the typical elongated appearance described by Grant (1959) for Tamm-Horsfall protein were evident, running from the origin to the $\alpha_{1}$-globulin region, between the 'cast Tamm-Horsfall protein' and both the anti-cast antiserum and the antiTamm-Horsfall antiserum (Figs. 3 and 4). As for alkali-treated Tamm-Horsfall protein, two lines are seen in Fig. 4.

On gel-diffusion (Ouchterlony, 1958) against anti-Tamm-Horsfall antiserum, reaction of identity was given by the 'cast Tamm-Horsfall protein' and Tamm-Horsfall protein from normal urine (Fig. 5).

No serum proteins could be demonstrated in the 'cast-deposit' material. However, serum proteins in the casts might not be expected to be present in this material. Water-soluble proteins such as albumin, going into solution in alkalinized distilled 


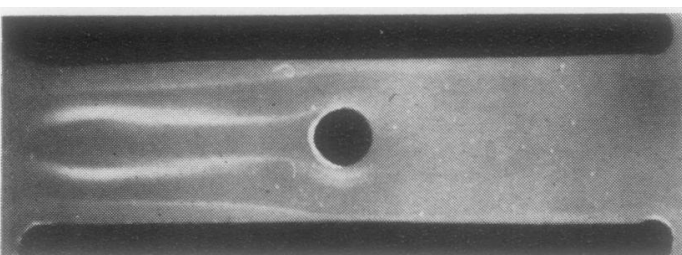

FIG. 3

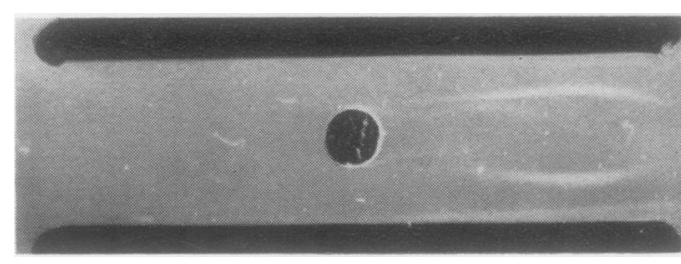

FIG. 4

FIG. 3. Cast material subjected to immuno-electrophoresis ( $\mathrm{pH} 8.6)$. Troughs: Upper, anti-Tamm-Horsfall antiserum (undiluted). Lower, anti 'cast-Tamm-Horsfall' antiserum (undiluted). Hole: Cast material $6 \mathrm{mg} . / \mathrm{ml}$. diluted 1:1 with M/201 $\mathrm{NaOH}$.

FIG. 4. Cast material subjected to immuno-electrophoresis ( $p \mathrm{H} \mathrm{8.6).} \mathrm{Troughs:} \mathrm{Upper,} \mathrm{anti-Tamm-Horsfall} \mathrm{antiserum}$ (undiluted). Lower, anti-'cast-Tamm-Horsfall' antiserum (undiluted). Hole: Cast material $6 \mathrm{mg} . / \mathrm{ml}$. diluted $1: 7$ with M/20 $\mathrm{NaOH}$. The double line produced in Tamm-Horsfall proteins by treatment with alkali is again evident here.

water with the Tamm-Horsfall component, would not be reprecipitated by $\mathrm{NaCl}$ at $0.58 \mathrm{M}$ concentration, and would remain in the 'cast supernatant'. A small amount of albumin and traces of $\gamma$ globulin and siderophilin could in fact be demonstrated in the 'cast supernatant' after concentration by dialysis. The amount of albumin, estimated by the quantitative gel-diffusion technique (Gell, 1957) is shown in Table I and compared with the amount of TammHorsfall proteins in one preparation.

It is clear that serum proteins did not account for more than a minute fraction of the material of which the casts were composed, and it appears likely that this consisted very largely of Tamm-Horsfall protein.

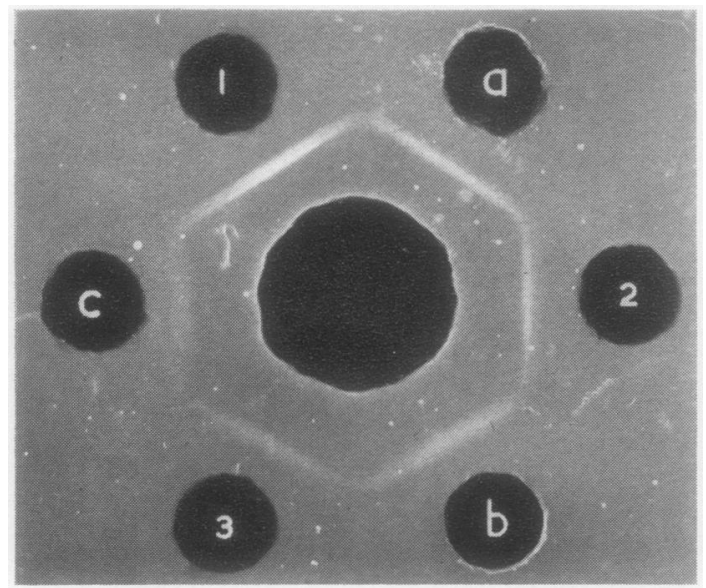

FIG. 5. Gel diffusion precipitin reaction. Reaction of identity between cast material and Tamm-Horsfall protein. Centre hole Anti-Tamm-Horsfall antiserum

Peripheral holes 1, 3, 5, Tamm-Horsfall protein, increasing dilutions in $\mathrm{M} / 20 \mathrm{NaOH} \mathrm{a}, \mathrm{b}$, c, cast material, increasing dilutions in $\mathrm{M} / 20 \mathrm{NaOH}$.

\section{TABLE I}

RELATIVE AMOUNTS OF PROTEIN IN CAST PREPARATION FROM URINE SPECIMEN OF NEPHROTIC PATIENT M.W

Tamm-Horsfall protein

Albumin from cast solution after precipitation of above $21 \mathrm{mg} \subseteq$ $0.4 \mathrm{mg}$

The conditions which might lead to the precipita tion of the Tamm-Horsfall protein in cast form in urine have also been investigated. Table II shows tho excretion rate of Tamm-Horsfall protein as estimate by the method outlined, urinary Tamm-Horsfa耳 protein concentration, urinary volume, urinare total protein concentration, total protein excretion? and number of casts per hour in five nephrotic an $\overrightarrow{\mathbb{E}}$ five normal subjects. Included also are data frorm one subject with chronic active pyelonephritis. The excretion rate in normal subjects as estimate corresponded reasonably well with the dry weight estimations of Boyce and Swanson (1955), namely $46 \mathrm{mg}$. per 24 hours.

It can be seen that neither total excretion nog concentration of Tamm-Horsfall protein were necessarily greater in patients who formed casts than in those who did not. The Tamm-Horsfat excretion rate was in general greater in patients with renal disease than in the normal subjects. Amongș those forming casts the patient with the most cas $\$$ had the highest urinary concentration of Tamnu Horsfall protein. However, this was not greater thang that in the urine of the patient with pyelonephritis io whom no casts were seen. The only invariable association with cast formation was that whic common clinical experience would indicate, namelse the presence of significant amounts of serum proteins in the urine. The effect of adding serum proteins to solutions of Tamm-Horsfall protein wo therefore investigated in vitro. The following exper ments were all carried out in neutral solution.

The effect of the addition of serum albumin wa্s investigated first, and it was found that solutions 
TABLE II

TOTAL TAMM-HORSFALL PROTEIN EXCRETION AND OTHER FACTORS IN CAST FORMATION

\begin{tabular}{|c|c|c|c|c|c|c|c|}
\hline & & Volume/Hour & $\begin{array}{l}\text { Tamm-Horsfall } \\
\text { Concentration } \\
(m g . \%)\end{array}$ & $\begin{array}{l}\text { Tamm-Horsfall } \\
\text { Excretion Rate } \\
\text { (mg./hr.) }\end{array}$ & $\begin{array}{l}\text { Total Urine } \\
\text { Protein } \\
(\mathrm{g} . \%)\end{array}$ & $\begin{array}{l}\text { Na Concentra- } \\
\text { tion } \\
(m E q . / \text { litre })\end{array}$ & $\begin{array}{l}\text { No. of Casts } \\
\text { per Hour }\end{array}$ \\
\hline Normal subjects & $\begin{array}{l}\text { C.M. } \\
\text { J.E. } \\
\text { E.M. } \\
\text { M.M. } \\
\text { P.M. }\end{array}$ & $\begin{array}{l}68 \\
50 \\
46 \\
28 \\
24\end{array}$ & $\begin{array}{l}2 \cdot 4 \\
3 \cdot 0 \\
3 \cdot 6 \\
3 \cdot 7 \\
3 \cdot 3\end{array}$ & $\begin{array}{l}1.5 \\
1.4 \\
1.6 \\
1.0 \\
0.8\end{array}$ & $\begin{array}{l}\mathbf{0} \\
\mathbf{0} \\
\mathbf{0} \\
\mathbf{0} \\
\mathbf{0}\end{array}$ & $\begin{array}{r}70 \\
99 \\
126 \\
129 \\
100\end{array}$ & $\begin{array}{l}0 \\
0 \\
0 \\
0 \\
0\end{array}$ \\
\hline Nephrotic patients & $\begin{array}{l}\text { D.B. } \\
\text { J.B. } \\
\text { P.M. } \\
\text { J.L. } \\
\text { M.W. }\end{array}$ & $\begin{array}{l}94 \\
77 \\
73 \\
63 \\
20\end{array}$ & $\begin{array}{r}3 \cdot 5 \\
8 \cdot 5 \\
2 \cdot 7 \\
2 \cdot 3 \\
11 \cdot 7\end{array}$ & $\begin{array}{l}3 \cdot 3 \\
5 \cdot 1 \\
1 \cdot 9 \\
1 \cdot 4 \\
2 \cdot 4\end{array}$ & $\begin{array}{l}1 \cdot 0 \\
0.9 \\
0.3 \\
0.4 \\
1 \cdot 7\end{array}$ & $\begin{array}{l}25 \\
12 \\
12 \\
15 \\
15\end{array}$ & $\begin{array}{r}6.1 \times 10^{4} \\
1.5 \times 10^{4} \\
2.1 \times 10^{4} \\
2.4 \times 10^{4} \\
11.2 \times 10^{4}\end{array}$ \\
\hline Pyelonephritis & P.W. & 40 & 11.8 & $4 \cdot 6$ & 0 & 116 & 0 \\
\hline
\end{tabular}

TABLE III

DEGREE OF FLOCCULENT PRECIPITATION AFTER ADDING ONE DROP OF TAMM-HORSFALL PROTEIN TO AQUEOUS SOLUTIONS OF ALBUMIN

\begin{tabular}{llllllllll}
$\begin{array}{l}\text { Albumin Concentration } \\
(\mathrm{g} . \%)\end{array}$ & 3.5 & 1.75 & 0.88 & 0.44 & 0.22 & 0.11 & 0.06 & 0.03 & Nil \\
\hline Deposit & ++++ & +++ & +++ & +++ & ++ & + & 0
\end{tabular}

of albumin in distilled water were particularly effective in producing precipitation of the TammHorsfall protein in quite low dilutions. Table III shows the degree of flocculent precipitate evident on the addition of a drop of a concentrated aqueous suspension of Tamm-Horsfall protein to each of a series of tubes containing progressively diminishing concentrations of 'salt-free' human serum albumin.

When, however, the same experiment was performed using solutions of albumin in saline instead of distilled water, the effect of albumin was found to be considerably less marked. Furthermore, when solutions of albumin in normal urine were used, the degree of Tamm-Horsfall protein precipitation was still further lessened.

To make a quantitative assessment of the extent of precipitation of Tamm-Horsfall protein by solutions of albumin in various solvents, 8 drops of the above suspension (=approximately $1.2 \mathrm{mg}$. Tamm-Horsfall protein) were added to $8 \mathrm{ml}$. of water, saline, and normal urine with and without albumin ( $1 \%$ concentration) and also to $8 \mathrm{ml}$. of previously centrifuged urine from a nephrotic subject which contained $1.05 \mathrm{~g} . \%$ protein, nearly all albumin, and but little sodium (10 mEq./litre). Any deposit forming was separated by centrifugation and then washed three times in $0.58 \mathrm{M} \mathrm{NaCl}$, shaking carefully each time. By the use of ${ }^{131}$ Ilabelled albumin it was shown that washing in this manner reduced contaminating albumin in the final precipitate (see later) to insignificant amounts. The quantity of Tamm-Horsfall protein remaining in each tube was estimated by the Folin-Ciocalteu reaction. The spectrophotometer readings obtained were compared with that given by 8 drops of TammHorsfall protein suspension and the results expressed as percentages of the latter reading (Table IV).

\section{TABLE IV}

AMOUNT OF TAMM-HORSFALL PROTEIN PRECIPITATED ON ADDING 0.6 MG. TAMM-HORSFALL PROTEIN TO $8 \mathrm{ML}$. OF VARIOUS SOLUTIONS EXPRESSED AS PERCENTAGE OF ADDED TAMM-HORSFALL PROTEIN

Solution

Tamm-Horsfall
Protein

Precipitated (\%)

Distilled water

Distilled water $+1.0 \%$ albumin

Isotonic $0.85 \% \mathrm{NaCl}$

Isotonic $0.85 \% \mathrm{NaCl}+1.0 \%$ albumin

Normal urine

Normal urine $+1 \%$ albumin

Nephrotic urine (contains $1.05 \%$ protein)

0
95
83
72
0
17
30

The markedly inhibitory effect of normal urine on the precipitation of Tamm-Horsfall protein by albumin was less marked with specimens of nephrotic urine, possibly by reason of their low $\mathrm{NaCl}$ content.

The interaction between Tamm-Horsfall protein and albumin in aqueous solution was further investigated by the use of ${ }^{131}$ I-labelled albumin. A $0.1 \%$ solution of ${ }^{131}$ I-labelled albumin was prepared and to $10 \mathrm{ml}$. aliquots of this was added $1.5 \mathrm{mg}$. Tamm-Horsfall protein. Following centri- 
fugation and separation of the resulting precipitate, the activity of the supernatant solution was measured and compared with the original solution. It was found that activity of the supernatant had diminished by $14.3 \%$, indicating that albumin had been carried down with the Tamm-Horsfall protein. It would thus appear that this experiment, although suggesting the reason for the precipitation of TammHorsfall protein in cast form in patients with proteinuria, does not constitute an exact model of the processes leading to the formation of hyaline casts, in which, as has been seen, only very small amounts of albumin could be demonstrated. However, modification of the interaction between TammHorsfall protein and albumin by the other constituents of urine has already been suggested by the lesser proportion of Tamm-Horsfall protein precipitated by albumin when urine was used as the solvent.

On subsequent washing of the precipitate as for the quantitative estimation of Tamm-Horsfall protein precipitation, residual activity amounted to only $2.5 \%$ of that initially present. Only insignificant amounts of albumin apparently remained after washing.

The special effectiveness of serum albumin in tending to precipitate Tamm-Horsfall protein does not seem to be shared by $\gamma$ globulin, although the relative insolubility of $\gamma$ globulin itself made it difficult to assess its effect accurately. Haemoglobin had no tendency to precipitate Tamm-Horsfall protein.

The development in myelomatosis of renal insufficiency associated with the presence of dense casts in the kidney suggested a trial of Bence-Jones protein. A sample of Bence-Jones protein was even more effective in precipitating Tamm-Horsfall protein. Although the initial precipitate was not so bulky as that formed by interaction of TammHorsfall protein with albumin-containing solutions, recovery of Tamm-Horsfall protein amounted to $107 \%$, i.e., some of the Bence-Jones protein remained attached to the Tamm-Horsfall protein and was not removed by the washing procedure.

\section{DISCUSSION}

These experiments appear to indicate that hyaline casts are not, as is generally thought, principally composed of precipitated plasma proteins but consist largely of the mucoprotein described by Tamm and Horsfall (1950, 1952). However, small amounts of serum albumin were also found to be present.

The Tamm-Horsfall protein, which has been shown (Grant, 1959; Boyce, King, and Fielden,
1961) to be immunologically identical with that isolated from urine by various other methods (Di. Ferrante and Popenoe, 1958; Boyce, King, Little and Artom, 1958; Maxfield, 1959) is normally present in urine and appears to be derived from thg kidney. I have confirmed the finding that it is now detectable in blood (Grant, 1959; Boyce et al., 1961) although the latter workers found immunologicaf reactions of partial identity between this urinary mucoprotein and various tissue extracts. The $\vec{\phi}$ suggested that it might be related to a component of tissue 'ground substance'. Tamm, Bugher, anf Horsfall (1955), Porter and Tamm (1955), and Maxfield $(1959,1960,1961)$ have demonstrated the physical characteristics of Tamm-Horsfall proteing which was shown to exist in the form of longt flexible, rod-like molecules of very large size Maxfield (1961) has shown that under physiologicad conditions the predominant form has a molecular weight of $28 \times 10^{6}$ and is made up of four substituent $7 \times 10^{6} \mathrm{M}$.W. units which in turn can b subdivided into four $1.7 \times 10^{6} \mathrm{M}$.W. units. Increased

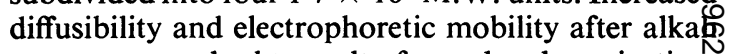
treatment no doubt results from depolymerization.

Maxfield (1959) has remarked on the tendency of Tamm-Horsfall molecules to form tactoids in sa solutions of even quite low concentration (more tha $0.03 \mathrm{M}$ ). However, this tendency alone is obviouslo not enough to explain the pathogenesis of casts? Crystalloid concentration of urine is often enoug $\overrightarrow{\vec{B}}$ in normal subjects to produce aggregation of Tamm Horsfall protein into precipitable masses ('nube culae'), accounting for almost all the TammHorsfall protein present without there being ang casts. Neither does the concentration of Tamm: Horsfall protein in urine correlate with cast for mation, as might be the case if the tendency to forig tactoids were the sole explanation.

The one factor which does seem invariablos associated with the presence of casts is the presence in the urine of significant concentrations of plasm proteins. It has been found that serum albumin $\overline{\bar{S}}$

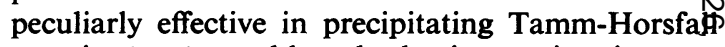
protein in vitro, although the interaction is mosis marked in salt-free solutions and is inhibited by the्छ presence of salt and particularly by normal urine Nephrotic urine, however, appears to have a leş markedly inhibitory effect, and it seems likely thef under the conditions obtaining in the oliguric phase of the nephrotic syndrome the situation in the distat portion of the nephron would be most favourable to the Tamm-Horsfall albumin interaction. A hig concentration of albumin would then coexist with high concentration of Tamm-Horsfall protein (as a result of the oliguria) in the presence of a virtually sodium-free urine. , 
I wish to express my gratitude to Professor J. R. Squire for affording me the facilities for this work.

It is a great pleasure also to acknowledge the invaluable assistance and advice given by Dr. John Hardwicke. I am additionally much indebted to Dr. J. F. Soothill for the quantitative gel-diffusion estimation of serum protein concentrations in cast material.

\section{REFERENCES}

Addis, T. (1929). Harvey Lect., 1927-1928, Series XXIII, p. 222. (1948). Glomerular Nephritis, p. 38. Macmillan, New York

Allison, A. C., and Humphrey, J. H. (1960). Immunology, 3, 95.

Boyce, W. H., King, J. S. Jr., and Fielden, M. L. (1961). J. clin. Invest., 40, 1453.

King, J. S., Little, J. M., and Artom, C. (1958). Ibid., 37, 1658.

- , and Swanson, M. (1955). Ibid., 34, 1581 .

Curtain, C. C. (1953). Aust. J. exp. Biol. med. Sci., 31, 615.
Di Ferrante, N., and Popenoe, E. A. (1958). Scand. J. clin. Lab. Invest., 10, Suppl. 31, p. 268.

Elek, S. D. (1948). Ph.D. Thesis, Univ. London. Brit. med.J., 1, 493. Fishberg, A. M. (1954). Hypertension and Nephritis, 5th ed., pp. 133-139. Baillière, Tindall and Cox, London.

Gell, P. G. H. (1957). J. clin. Path., 10, 67.

Grant, G. H. (1959). Ibid., 12, 510.

Hardwicke, J. (1954). Biochem. J., 57, 166.

Maxfield, M. (1959). Arch. Biochem., 85, 382. (1960). Ibid., 89, 281.

(1961). Biochim, biophys. Acta (Amst.), 49, 548.

Oliver, J. (1945). Harvey Lect., 1944-1945, Series XL, p. 102.

Ouchterlony, O. (1958). Progr. Allergy, 5, 1.

Porter, K. R., and Tamm, I. (1955). J. biol. Chem., 212, 135.

Soothill, J. F. (1962). J. Lab. clin. Med. (In press.)

Tamm, I., Bugher, J. C., and Horsfall, F. L. Jr. (1955). J. biol. Chem., 212,125 .

- and Horsfall, F. L. Jr. (1950). Proc. Soc. exp. Biol. (N. Y.), 74, 108. (1952). J. exp. Med., 95, 71.

Vaerman, J. P., and Heremans, J. F. (1959). Experientia (Basel), 15, 226.

Williams, C. A., and Grabar, P. (1955). J. Immunol., 74, 158. 